\title{
3 Reporting resource use in Germany
}

\author{
Stephan Lutter, Stefan Giljum, \\ Christopher Manstein, and Gerda Palmetshofer
}

\section{Resource use and sustainable development}

Natural resources are the biophysical basis for any society's development (UN IRP 2017a). Consequently, the use and management of natural resources plays a very prominent role in the United Nations Sustainable Development Goals (SDGs; United Nations 2015a). SDGs 6 and 14 tackle water, Goal 7 energy, Goal 13 the climate and the atmosphere, and Goal 15 land. Raw materials are covered in two SDGs: Goal 8, with its focus on economic growth as a driver of development, formulates target 8.4 to decouple economic growth from environmental degradation. The indicators used to monitor progress stem from Material Flow Analysis (MFA) on the economy-wide level (Eurostat 2018). Goal 12 on sustainable consumption and production promotes, among other aspects, resource and energy efficiency in production and consumption activities. Target 12.2 is about the sustainable management and efficient use of natural resources and uses the same MFA-based indicators as target 8.4. These two targets are among the few, which clearly identify a methodology for how to calculate the identified indicators. Further, they are the only two targets, which include a footprint-type indicator taking into account raw materials needed along global supply chains of products and services to satisfy the final demand of a country. The indicator used is called 'material footprint' or 'Raw Material Consumption' (RMC). This indicator accounts for raw material uses, which occur abroad, but contribute to domestic final demand, are termed 'indirect flows' or 'raw material equivalents of traded goods' (Eurostat 2018; Maier 2018).

UN Environment (UNE) is the custodian for 26 environment-related indicators used to monitor the achievement of the SDGs. UNE and its suborganisation, the International Resource Panel (IRP), regard MFA as a flagship statistical product for both the SDGs and measuring resource efficiency at the national level. The UN IRP aims to refine and harmonise the MFA methodology, to build capacity among countries and to engage with countries to foster the compilation of MFA accounts by national statistical offices. For this reason, the UN IRP commissioned the development of a global MFA database and a related manual (to be approved by the UN Statistics Division) to support 
countries in their efforts to compile national MFA (UN IRP 2017b; UNSD 2019). Together with the UN Lifecycle Initiative and the One Planet Network, the UN IRP also commissioned the Sustainable Consumption and Production Hotspots Analysis Tool (SCP-HAT; scp-hat.lifecycleinitiative.org). The tool illustrates a country's performance in the context of SDGs 8 and 12 and supports countries in their endeavours to design SCP-related policies.

The OECD supports countries in implementing the UN 2030 Agenda for Sustainable Development (United Nations 2015b) by contributing its strong track record in policy assessments and the development of indicators for monitoring performance. In this context, the OECD coordinates a process aiming at harmonising methods for consumption-based indicators such as the material footprint used in SDG 8 and 12, to ensure a methodologically sound monitoring process (OECD 2018).

The concept of resource efficiency as a means to achieve decoupling was also taken up in the EU Roadmap to a Resource-Efficient Europe (European Commission 2011) and its successor, the Circular Economy Action Plan (European Commission 2015). The European Environment Agency (EEA) is regularly examining strategies, instruments and targets for materials and resource efficiency and circular economy in 32 European countries (EEA 2016). According to preliminary information from the EEA, until 2018 at least eighteen European countries (including sixteen EU member states) had carried out activities to support the development of respective policies, strategies or roadmaps (EEA 2020).

The G7 countries recognise the importance of resource efficiency for environmental protection, climate protection, sustainable development and economic competitiveness. The G7 adopted its first decisions regarding resource efficiency under the German presidency in 2015. In that year, the G7 launched its Alliance on Resource Efficiency as a new forum for cooperation. At their summit in Hamburg on 7-8 July 2017, the G20 countries decided to establish the Resource Efficiency Dialogue to cooperate more closely on the efficient and sustainable use of natural resources. Also, just recently, at their meeting in Metz, in May 2019, G7 representatives strongly encouraged the UN IRP to continue its work to strengthen knowledge of resource efficiency and related topics such as the circular economy and innovative energy solutions.

\section{Resource efficiency policies in Germany}

Germany can be considered a frontrunner in recognising increased resource efficiency as a means to achieve sustainable economic development. In the early 1990s, Friedrich Schmidt-Bleek postulated an increase of resource productivity of industrialised countries by a 'Factor of 10' (minus 90\%), as a response to the fact that the wealthiest countries have a significantly higher consumption than the world's poorest countries (Schmidt-Bleek 1993). Today the generalised term 'Factor $\mathrm{X}$ ' is often used, as the required degree of dematerialisation needs to be decided individually from country to country, 
according to the current levels of consumption (Lehmann, Schmidt-Bleek \& Manstein 2018).

In the first 'German Sustainability Strategy' (Deutsche Bundesregierung 2002), raw material productivity, calculated as GDP divided by the MFAbased indicator 'Abiotic Domestic Material Input' was included as one core indicator. Following the Factor $\mathrm{X}$ debate, the target for the increase in raw material productivity was set at a factor of two for the period 1994 to 2020, including a long-term improvement based on a 'Factor 4' vision.

The Resource Efficiency Programme (ProgRess), first published in 2012, made Germany one of the first countries adopting a national strategy by the federal government and identifying specific resource efficiency measures (BMU 2012). ProgRess focuses on the resource category of 'raw materials' and aims at continuously improving raw material productivity in Germany across the entire value chain, covering extraction of raw materials, production, consumption, re-use and recycling. This increased productivity shall help decoupling economic growth from resource consumption and its environmental impacts. In March 2016, ProgRess II was published (BMUB 2016), and work is currently underway for the publication of ProgRess III, which is expected for spring 2020.

In ProgRess II, an additional productivity indicator - 'Total Raw Material Productivity', which is calculated as GDP plus imports divided by the indicator Raw Material Input (RMI), complemented the indicator raw material productivity. RMI also includes raw materials that are needed abroad for the production of imported goods (see above). Closely linked to the revised German Sustainability Strategy (Federal Government 2017), ProgRess II sets a target of continuing the trend of the period 2000-2010 until the year 2030, meaning an average annual increase of $1.5 \%$ for the period 2010 to 2030 .

\section{Reporting resource use in Germany}

The reporting and monitoring of resource use in Germany is framed by the two main political strategies described above - and the German Sustainability Strategy and ProgRess. Since the adoption of the UN SDGs, the German administration aimed at integrating the two national strategies and their related indicators and targets with the overarching global goals. The indicator report on sustainable development in Germany published biannually by the Germany Statistical Office (Destatis 2018) officially monitors progress. The report allocates the indicators as defined for the national Sustainability Strategy to the 17 SDGs, resulting in a very comprehensive monitoring framework. However, the applied indicators deviate considerably from the indicators agreed upon at the UN level. For example, for targets 8.4 and 12.2, the main indicator on the UN level is the consumption-based material footprint (RMC). It is used in absolute, per-capita and per-GDP terms. In contrast, Destatis reports only the input-based indicator 'Total Raw Material Productivity' (see above). Another example is SDG 6 (Water), where one of 
the SDG indicators is water efficiency, which is not included in the German indicator report.

The second regular publication on natural resource use in Germany is the indicator report series 'Data on the Environment' published by the German Environment Agency (UBA 2017). UBA provides a comprehensive overview of the state of the environment in Germany and identifies the actors responsible for environmental pollution as well as starting points for improving measures. To this end, 50 indicators are reported that cover all environmental areas. Where available, the indicators are backed up by existing political objectives - for example stemming from the German Sustainability Strategy, ProgRess, or from EU directives. For this reason, the system of environmental indicators also represents a balance sheet of environmental policy. The reported key indicators include raw material productivity and total raw material productivity (see above).

\section{The research project 'Resource Use in Germany'}

In addition to increasing technical efficiency in German industry and small and medium-sized enterprises (Schmidt, Spieth, Haubach \& Kühne 2018), raising the awareness among important stakeholder groups such as politicians, consultants, entrepreneurs, scientists, teachers, pupils, journalists, and civil society is another one of the critical factors to achieve sustainable resource use. However, existing indicator reports often are not suitable for a broader circle of readers, as they do not analyse and interpret the complex topic of natural resources use in an appropriate manner.

To fill this existing gap, UBA launched the research project 'Resource Use in Germany' (UBA 2014). Aim of DeuRess was to develop the scientific concept and to start implementing a regular report series called 'Resource Use in Germany', which not only compiles but also analyses and interprets statistics on resource use, including comparisons over time. The series is meant to explain the causes and effects of resource use as well as the correlations between different categories of natural resources ('nexus'). By making the successes of and needs for corresponding environmental policy strategies and programmes visible, the topic shall be made more prominent to support the Resource Efficiency Programme (ProgRess) and to complement other existing reports and statistics.

The research work started with defining the specific target groups of the report series, screening similar reports on the national and international level as well as assessing available data and indicators on resource use in Germany and related methodological options. The initially broad range of target groups was narrowed down to representatives, who have a certain level of interest in the topic as well as previous knowledge, and due to their working areas can act as communication multipliers to support the transition towards a more sustainable resource use.

22 national and international reports were assessed according to a set of criteria, such as their geographical and temporal focus, the sectoral detail, the 
applied data, and the graphic design. Examples for reports with a similar topic are 'The Global Resource Footprints of Nations' (Tukker et al. 2014) or the 'Decoupling Report' by the UN IRP (UNEP 2011). Reports with a similar target group but a differing topic were, for instance, the 'Living Planet Report' by WWF and partners (WWF, Zoological Society of London, Global Footprint Network \& Water Footprint Network 2014) or the soil and meat atlases of the Heinrich Böll Foundation (Heinrich Böll Stiftung \& FoEE 2014; Heinrich Böll Stiftung \& IASS 2015). The main conclusions drawn were that the thematic focus should be set on the extraction of raw materials, their trade, the relationship between raw materials and economic performance, and their use for consumption purposes. Moreover, the main structural approach should be to present the content in small self-contained 'packages' of one double page each with a synoptic paragraph at the beginning ('teaser'), a main graph and additional elements such as tables, boxes or additional figures.

Regarding the stocktaking on available data, publications by the Federal Statistical Office (Destatis) were identified as the main source. As part of the annual report series 'Environmental Economic Accounting (UGR)' (Destatis 2019), Destatis publishes detailed data on raw material extraction within Germany as well as on direct imports and exports of raw materials. The UGR also contains some data on water and land use of lower timeliness and detail. Besides, Destatis provides papers and publishes indicators on the indirect flows of German imports and exports (Kaumanns \& Lauber 2016; Maier 2018). As part of the stocktaking, also international data sources were examined, including the Material Flow Accounts published by Eurostat (2019), OECD's Environment Statistics on material resources (OECD 2019), or the above mentioned Global Material Flows Database by the UN IRP (2017b).

Criteria used to carry out the analysis encompassed the geographical coverage of the dataset, its disaggregation regarding material categories and economic sectors, timeliness, data quality, and coverage of direct and indirect resource flows. The results showed that, apart from official data from national sources, the data sets from EUROSTAT and the IRP, as well as publicly accessible global economic-environmental models like EXIOBASE (Stadler et al. 2018) should play an important role, especially for the European and international comparison of indicators on direct and indirect material flows.

\section{The new report series: concept and design}

An important content-related decision at the very beginning of the conceptualisation process was to focus the report series on the resource category of raw materials, and to describe the use of other resources in one separate chapter only, thus following the priority setting of ProgRess.

Each report of the series consists of three main parts: (1) An introductory chapter provides the overall thematic context, a table of contents, key indicators of the report, and the methodological foundations. (2) Five main chapters cover the identified relevant topics - extraction, trade, economic use 
and decoupling, consumption and other resources than raw materials. (3) A separate data section summarises the numbers and data used in the report. Each of the five main chapters starts with an 'intro page' showing the key figures of each chapter in synergy with a representative thematic image. Furthermore, each chapter is divided into four to five sub-topics, each elaborated on one double page forming a closed section. This structure and design, together with an easy-to-understand guidance system, enables readers to choose between selecting one specific sub-topics of interest or flick through the whole report from the beginning to the end, always maintaining the contextual orientation.

As regards data and methods, the report series builds upon the aboveexplained environmental economic accounts (UGR) for the analysis of domestic extraction and direct trade of raw materials. The most recent raw material data available refer to the year 2015. With respect to indirect raw material flows, the new resource series draws upon two sources. The first is a model maintained by Destatis, which focuses on Germany and provides data for the period from 2010 to 2014 and, in an earlier version, for 2000-2010 (Kaumanns \& Lauber 2016; Maier 2018). These data were used for all Germany-specific analyses. The second data source is the model EXIOBASE 3.3 (www.exiobase.eu; Stadler et al. 2018), which has a global coverage, distinguishing 49 countries and country groups and currently provides data for a time series from 1995-2014. Due to differences in the underlying methodologies, the figures from Destatis tend to produce lower results than those based upon the EXIOBASE calculations, and thus the two are not directly comparable. Results from the EXIOBASE calculations were therefore used primarily for analyses regarding the structure of international supply chains, for international comparisons as well as for analysing consumption areas like food or health.

\section{Key results of the German Resource Report 2018}

The report series encompasses so far two resource reports, published in the years 2016 and 2018 (UBA 2016, 2018). The following section summarises the main findings of the recent German Resource Report (UBA 2018). It is divided into the same sub-sections as the report series.

\section{Domestic raw material extraction}

In 2015, 1,040 million tonnes of non-renewable and renewable raw materials were extracted in Germany. While this represents an overall reduction since 1994, extraction of renewable raw materials increased by $28 \%$. These are used not only for the production of foodstuffs but increasingly also as fuels and construction materials as well as in the pharmaceutical industry.

Raw materials extraction is very unevenly distributed among Germany and concentrated within a few of the larger federal states. In 2015, almost a quarter (243 million tonnes) of total domestic extraction took place in North 
Rhine-Westphalia (NRW). The per-capita perspective provides an entirely different picture, however. Given its high population density, NRW was below the average federal per-capita extraction figure of 13.7 tonnes in 2015, while Saxony-Anhalt took pole position with almost 30 tonnes per capita (Figure 3.1).

\section{Germany's share in global raw material trade}

Germany is a trading nation. Raw materials and goods are imported, further processed, and a significant amount of raw materials, processed goods and final products is (re-)exported. While in 2015, Germany's imports exceeded exports by 243 million tonnes, at the same time it generated a monetary trade surplus of 265 billion Euro. This apparent discrepancy can be explained by the fact that the manufacture of higher-value products increases the value per tonne of raw materials.

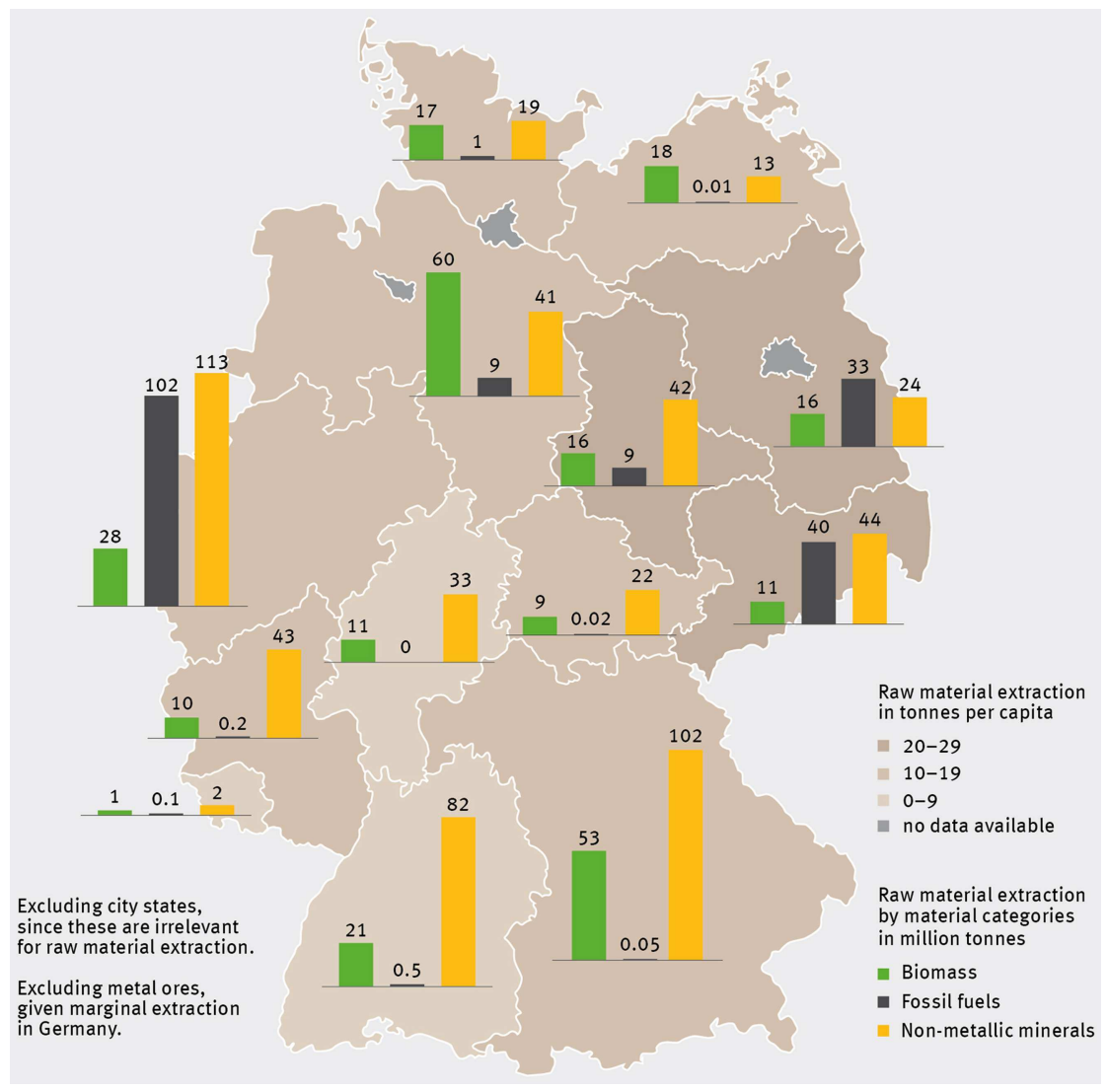

Figure 3.1 Used raw material extraction in the German federal states, 2015. Source: UBA (2018). 
As explained above, all semi-finished and finished goods imported into Germany contain indirect raw material flows. When these indirect flows are accounted for, Germany's physical trade volumes increase by almost a factor of 3 . Indirect raw material flows of imports increased sharply in the past years and comprised 919 million tonnes by 2014. About 58\% of the raw materials processed in the German economy were non-domestic in origin.

\section{The role of the economy}

A sustainable use of natural resources means increasing raw material productivity, hence decoupling economic growth from raw material use and its negative environmental impacts. Germany's raw material productivity, i.e. the relationship between GDP and direct material input (see above), increased by 56\% during the period 1994-2015 (Figure 3.2). The indicator of total raw material productivity, which also takes account of the indirect material flows of imports to Germany, rose in recent years by an average of $1.9 \%$ per year. This is above the goal identified in ProgRess II to maintain the growth rate seen during the period 2000-2010 of around 1.5\% until 2030.

\section{Raw materials for consumption}

Raw material consumption (RMC) of German final demand comprises all raw materials that are required along the supply chains of consumed products and services. In 2014, the per-capita figure was 16.1 tonnes, with an absolute amount of 1.3 billion tonnes. Although this represented a reduction since 2000

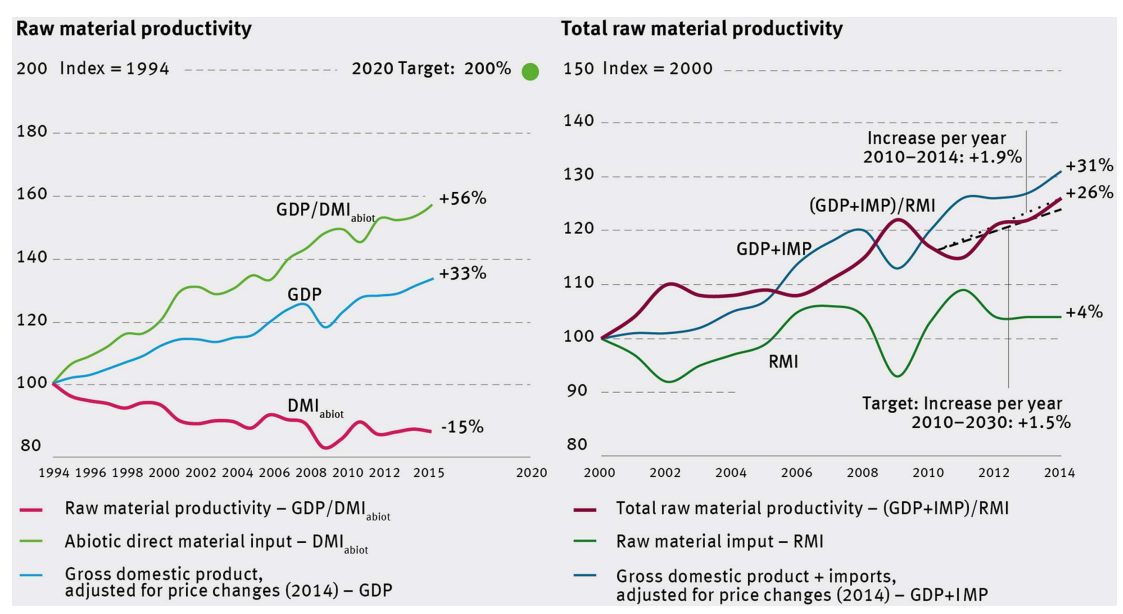

Figure 3.2 Development of raw material productivity, 1994-2015, (left) and total raw material productivity (right) in Germany, 2000-2014.

Source: UBA (2018). 
by $13 \%$, it increased again in the most recent years. Non-metallic minerals contributed the largest share to raw material consumption in 2014 (45\%), followed by fossil fuels (29\%) and biomass (21\%).

Public and private consumption were jointly responsible for almost twothirds of raw material consumption in Germany in 2014. With regard to private consumption, large quantities of raw materials were consumed in the areas of housing and food. The public sector's requirements for raw materials occurred primarily via the consumption of goods and services in the areas of administration, defence and health. The state's relatively high share in Germany's overall consumption reflects the key importance of the welfare state's role in the country.

\section{Other natural resources}

Since the extraction, processing and transport of raw materials and the use of products are all associated with significant energy inputs, greenhouse gas emissions occur along the entire value chain of raw materials. The use of raw materials and climate change are thus closely interlinked. It becomes evident that increasing the efficiency of raw materials use is an essential prerequisite for reaching climate goals.

When contrasting the carbon footprint and material footprint (RMC) with one another over time, it becomes evident that both curves follow a similar path. Both time series have the same downturns in 1997, 2002 and 2009, with the most accentuated in 2002, where the material footprint was at $87 \%$ of its 1995 value, and the carbon footprint at $88 \%$. Moreover, both time series have similar peaks, especially in the year 2007. This may be explained by the fact that increased product consumption also causes higher emissions along the supply chains. At the same time, the economic crisis of 2008 produced a slump both in the $\mathrm{RMC}$ indicator and in the $\mathrm{CO}_{2}$ footprint.

\section{Résumé and outlook}

The goal of the resource report series 'The Use of Natural Resources Report for Germany' is to explain the complex topic of resource use in a generally understandable way, setting its focus on raw materials. The content-related framework fulfils this requirement by applying an innovative concept consisting of a streamlined structure (double pages) and clear figures. The 'prototype' reports 2016 and 2018 introduced the topic to a wide audience and provided relevant data and facts. Follow-up reports will present updated data in a condensed manner while treating selected aspects in more detail.

The topic of resource use is intrinsically complex and relevant for a wide range of stakeholders, making the communication of the topic a challenge. The resource reports 2016 and 2018 addressed only a part of the target groups namely policy makers and advisors and researchers - in a meaningful way. 
One conclusion drawn is that future reports should keep setting their focus on these stakeholders and that additional formats are required for ensuring targeted communication to the other groups.

Both the German Environment Agency and Destatis provide data on the use of natural resources in Germany. One challenge was to present this data without duplication and, in areas where these two institutions do not provide data, to integrate data from other sources and to deal appropriately with deviating results from different calculation models. The approach of how to deal with the observed differences was openly discussed in the method description. The results were presented in a way that clearly communicates the actual message (e.g. large differences in national per-capita or sector numbers) while at the same time avoiding confusion due to diverging absolute values.

As regards a continuation of the resource report series, a number of aspects should be taken into consideration. One refers to data harmonisation. The existing reports showed an urgent need of further harmonising the UGR provided by Destatis with the global dataset provided by the UN IRP. In this context, the main question would be how to best use the Destatis data to increase the robustness of the global dataset. Similarly, future reports should tackle the issue of how to harmonise the Destatis approach to calculate indirect material flows with other, global approaches, in order to generate more congruent results.

Future reports will certainly update the core content, such as levels of domestic extraction, trade or raw material productivity. However, in addition, future reports could aim at demonstrating the intertwining between the use of raw materials and other resources such as water, land, or greenhouse gas emissions (the so-called resource nexus), as well as the environmental impacts caused by the use of raw materials.

Finally, the resource report series aims at addressing a large number of stakeholder groups and individuals in general, to create awareness and achieve a more sustainable societal resource use. To exploit the series' full potential and increase its distribution and uptake, a thoroughly developed communication strategy targeting different stakeholders with key messages from the report could accompany the publication. Further, a comprehensive web portal with interactive elements, which provides state-of-the-art visualisations, background material and relevant links to related initiatives could accompany the publication is foreseen.

The resource report series developed by the German Environment Agency is a successful attempt to make the topic of natural resource use in Germany, which is of central relevance for global sustainable development, more tangible. Furthermore, by that means, inform and motivate readers to become responsible and active citizens. UBA will continue the research project. 'DeuRess II' will start in autumn 2019, and the third German Resources Report as a key result of this next project is expected for 2022 . 


\section{Abbreviations}

$\begin{array}{ll}\text { EEA } & \text { European Environment Agency } \\ \text { FoEE } & \text { Friends of the Earth Europe } \\ \text { G7 } & \text { Group of Seven } \\ \text { G20 } & \text { Group of Twenty } \\ \text { GDP } & \text { gross domestic product } \\ \text { MFA } & \text { Material Flow Analysis } \\ \text { NRW } & \text { North Rhine-Westphalia } \\ \text { OECD } & \text { Organisation for Economic Co-operation and Development } \\ \text { RMC } & \text { raw material consumption } \\ \text { RMI } & \text { raw material input } \\ \text { SCP-HAT } & \text { Sustainable Consumption and Production Hotspots } \\ & \text { Analysis Tool } \\ \text { UBA } & \text { German Environment Agency } \\ \text { UNE } & \text { UN Environment } \\ \text { UN IRP } & \text { United Nations International Resource Panel } \\ \text { UN SDG } & \text { United Nations Sustainable Development Goals } \\ \text { WWF } & \text { World Wildlife Fund }\end{array}$

\section{References}

BMU (2012). Federal Ministry for the Environment, Nature Conservation and Nuclear Safety. German Resource Efficiency Programme (ProgRess). Berlin.

BMUB (2016). German Resource Efficiency Programme II. Berlin. Federal Ministry for the Environment, Nature Conservation, Building and Nuclear Safety (BMUB) website: www.bmu.de/en/topics/economy-products-resources-tourism/resource-efficiency/ overview-of-german-resource-efficiency-programme-progress.

Destatis (2018). Sustainable Development in Germany: Indicator Report 2018. Wiesbaden. Retrieved from Destatis - Statistisches Bundesamt Deutschland website: www.destatis.de/ DE/Themen/Gesellschaft-Umwelt/Nachhaltigkeitsindikatoren/Publikationen/ Downloads-Nachhaltigkeit/indicator-report-0230002189004.pdf?_blob=publicationFile.

Destatis (2019). Umweltökonomische Gesamtrechnungen: Methode des gesamtwirtschaftlichen Materialkontos. 2019. Wiesbaden. Retrieved from Destatis - Statistisches Bundesamt Deutschland website: www.destatis.de/DE/Themen/Gesellschaft-Umwelt/ Umwelt/Materialfluesse-Energiefluesse/Publikationen/Downloads-Material-undEnergiefluesse/gesamtwirtschaftliches-materialkonto-fb_5851314189004.pdf?_blob= publicationFile.

Deutsche Bundesregierung (2002). Perspektiven für Deutschland. Unsere Strategie für eine nachhaltige Entwicklung. Berlin.

EEA (2020). European Environment Agency. Even more from less. Copenhagen.

EEA (2016). European Environment Agency. More from Less - Material Resource Efficiency in Europe. 2015 Overview of Policies, Instruments and Targets in 32 countries. Copenhagen.

European Commission (2011). Roadmap to a Resource Efficient Europe (No. COM (2011) 571 final). Brussels.

European Commission. (2015). Closing the Loop - An EU Action Plan for the Circular Economy, $\operatorname{COM}(2015)$ 614. Brussels. 
Eurostat (2018). Economy-wide Material Flow Accounts: Handbook (2018 edition). Manuals and guidelines. Luxembourg: Publications Office of the European Union. Retrieved from https://ec.europa.eu/eurostat/documents/3859598/9117556/KS-GQ-18-006EN-N.pdf/b621b8ce-2792-47ff-9d10-067d2b8aac4b https://doi.org/10.2785/158567.

Eurostat (2019). Material Flow Accounts (Eurostat Database). Luxembourg. Retrieved from Statistical Office of the European Communities website: //appsso.eurostat.ec. europa.eu/nui/show.do?dataset=env_ac_mfa\&lang=en.

Federal Government (2017). German Sustainable Development Strategy. Berlin. website: www.bundesregierung.de/breg-en/issues/sustainability.

Heinrich Böll Stiftung \& FoEE (2014). Meat Atlas: Facts and Figures about the Animals We Eat. Germany. Retrieved from Heinrich Böll Stiftung; Friends of the Earth Europe website: www.boell.de/sites/default/files/meat_atlas2014_kommentierbar.pdf?dimension1=ds_ fleischatlas_2014.

Heinrich Böll Stiftung \& IASS (2015). Soil Atlas: Facts and Figures about Earth, Land and Fields. Germany. Retrieved from Heinrich Böll Stiftung; Institute for Advanced Sustainability Studies website: www.boell.de/sites/default/files/soilatlas2015_ii.pdf? dimension1=division_iap.

Kaumanns, S. \& Lauber, U. (2016). Rohstoffe für Deutschland: Bedarfsanalyse für Konsum, Investition und Export auf Makro- und Mesoebene. Destatis im Auftrag des Umweltbundesamt (UBA Texte No. 62/2016). Dessau-Roßlau. Retrieved from www. umweltbundesamt.de/sites/default/files/medien/1968/publikationen/rohstoffe_fur_ deutschland.pdf.

Lehmann, H., Schmidt-Bleek, F. \& Manstein, C. (2018). Factor X - 25 Years - 'Factor X Concept' Is Essential for Achieving Sustainable Development: In: Lehmann, H. (Ed.). Factor X. Challenges, Implementation Strategies and Examples for a Sustainable Use of Natural Resources. Springer: Berlin.

Maier, L. (2018). Rohstoffe weltweit im Einsatz für Deutschland: Berechnung von Aufkommen und Verwendung in Rohstoffäquivalenten (WISTA No. 2/2018). Wiesbaden.

OECD (2018). International Expert Workshop on Demand-Based Measures of Material Flows and Resource Productivity: Workshop report (No. ENV/EPOC/WPEI(2017)2/REV). Paris.

OECD (2019). Environmental Statistics: Material Resources. Paris. Retrieved from Organisation for Economic Co-operation and Development (OECD) website: https:// stats.oecd.org/index.aspx?r=783906.

Schmidt, M., Spieth, H., Haubach, C. \& Kühne, C. (2018). 100 Pioneers in Efficient Resource Management: Best Practice Cases from Producing Companies: Springer. Retrieved from https://books.google.at/books?hl=de\&lr=\&id=5559DwAAQBAJ\&oi=fnd $\& p g=$ PR5\&dq $=100+$ Pioneers + in + Efficient + Resource + Management\&ots $=1 S T O 7$ UMt9q\& sig=pirTn02NxHrOhS3L73N-8E-OBh4.

Schmidt-Bleek, F. (1993). Revolution in Resource Productivity for a Sustainable Economy. A New Research Agenda. Fresenius Environmental Bulletin, 2(8), 485-490.

Stadler, K., Wood, R., Bulavskaya, T., Södersten, C.-J., Simas, M., Schmidt, S. ... Tukker, A. (2018). EXIOBASE 3: Developing a Time Series of Detailed Environmentally Extended Multi-Regional Input-Output Tables. Journal of Industrial Ecology, 22(3), 502-515. https://doi.org/10.1111/jiec.12715.

Tukker, A., Bulavskaya, T., Giljum, S., Koning, A. de, Lutter, S., Simas, M. ... Wood, R. (2014). The Global Resource Footprint of Nations. Carbon, Water, Land and Materials Embodied in Trade and Final Consumption Calculated with EXIOBASE 2.1. Leiden/Delft/ Vienna/Trondheim. 
UBA (2014). DeuRess: Resource Use in Germany. Research project on behalf of the German Environment Agency (UBA). Retrieved from Umweltbundesamt website: www. umweltbundesamt.de/en/resource-use-in-germany.

UBA (2016). The Use of Natural Resources: Report for Germany 2016. Dessau-Roßlau. Retrieved from German Environment Agency website: www.umweltbundesamt.de/ resourcesreport2016.

UBA (2017). Data on the Environment: Indicator Report. Dessau-Roßlau. Retrieved from German Environment Agency website: www.umweltbundesamt.de/en/data.

UBA (2018). The Use of Natural Resources: Report for Germany 2018. Dessau-Roßlau. Retrieved from German Environment Agency website: www.uba.de/resourcesreport2018.

UN IRP (2017a). Assessing Global Resource Use: A System Approach to Resource Efficiency and Pollution Reduction: A Report of the International Resource Panel. Nairobi. Retrieved from United Nations Environment Programme website: www. resourcepanel.org/sites/default/files/documents/document/media/assessing_global_resource_use_amended_130318.pdf.

UN IRP (2017b). Global Material Flows Database: Version 2017. Paris.

UNEP (2011). Decoupling Natural Resource Use and Environmental Impacts from Economic Growth, A Report of the Working Group on Decoupling to the International Resource Panel. Fischer-Kowalski, M., Swilling, M., von Weizsäcker, E. U., Ren, Y., Moriguchi, Y., Crane, W., Krausmann, F., Eisenmenger, N., Giljum, S., Hennicke, P., Romero Lankao, P., Siriban Manalang, A., Sewerin, S. Nairobi.

United Nations (2015a). Sustainable Development Goals: 17 Goals to Transform Our World. New York. Retrieved from United Nations website: www.un.org/ sustainabledevelopment/sustainable-development-goals/.

United Nations (2015b). Transforming Our World: The 2030 Agenda for Sustainable Development: Resolution 70/1. New York. Retrieved from United Nations website: https://sustainabledevelopment.un.org/post2015/transformingourworld.

UNSD (2019). Global Economy Wide Material Flow Accounting Manual: Draft version 2019. New York.

WWF, Zoological Society of London, Global Footprint Network \& Water Footprint Network (2014). Living Planet Report 2014. Species and Spaces, People and Places. Gland, Switzerland. 